\title{
THE ORIGINS OF ECONOMIC NATIONALISM IN INTERWAR ESTONIA
}

\begin{abstract}
Martin KLESMENT
Population Research Centre, Estonian Interuniversity, Estonia pst. 7, 10143 Tallinn, Estonia; mklesment@yahoo.com

The paper observes the preconditions for the emergence of economic nationalism in Estonia. It is assumed that the emergence of economic nationalism in the 1930s had a certain ideological basis and was not merely an answer to the economic crisis. The general polarisation of economic thought in Estonia, especially during the Great Depression, is taken into account and, therefore, the growth of ideological arguments for economic nationalism is juxtaposed with the opposite, a critique of the elements of economic nationalism. It is concluded that the ideas of economic nationalism, which existed already in the 1920s, were reinforced during the Great Depression and developed into deliberate economic policy in the second half of the 1930s.
\end{abstract}

Not many academic works are available on Estonian economic nationalism, as well as on economic nationalism in general. ${ }^{1}$ A specific volume, including two case studies on the enterprise level, focuses on the second half of the 1930s, when nationalist economic policy was dominant in Estonia. ${ }^{2}$ Some other studies also refer to the existence of the problem in Estonia or treat national questions in economic context. ${ }^{3}$ These works speak about economic nationalism in Estonia after the coup of 1934. However, much less is known about the reasons and ideological grounds behind the rise of nationalist economic policy. Anu Mai Kõll and Jaak Valge suggest that the policy started as a series of emergency measures that were later

1 For economic nationalism in general see, for example, Szlajfer, H. (ed.). Economic Nationalism in East-Central Europe and South America 1918-1939. Geneve, Librairie Droz, 1990; Johnson, H. G. (ed.). Economic Nationalism in Old and New States. Chicago, University of Chicago Press, 1967; Burnell, P. Economic Nationalism in the Third World. Brighton, Wheatsheaf Books, 1986.

2 Kõll, A.-M., Valge, J. Economic Nationalism and Industrial Growth. State and Industry in Estonia 1934-1939. (Acta Universitatis Stockholmiensis. Studia Baltica Stockholmiensia, 19.) Stockholm, Almqvist \& Wiksell, 1998.

3 For instance, Pihlamägi, M. Majandusliku mõtte ajaloost Eestis: vabaturumajandus versus reguleeritud majandus. - Proceedings of the Estonian Academy of Sciences. Humanities and Social Sciences, 1996, 45, 3, 285-295; Kõll, A.-M. Economy and ethnicity in the hands of the state: economic change and the national question in twentieth-century Estonia. - In: Economic Change and the National Question in the Twentieth-Century Europe. Eds. A. Teichova, H. Matis, J. Patek. Cambridge, CUP, 2000. 
consolidated by authoritarian rule into a coherent policy. ${ }^{4}$ Though not attempting to renounce this argument, the present study aims at some elaboration of this issue. The paper suggests that certain ideological notions, which gained strength during the economic crisis, existed already in the 1920s. Ad hoc measures, which in the beginning were introduced as emergency means to cope with the crisis, began to support the ideology, resulting in a general turn towards nationalist economic policy. The paper intends to demonstrate that economic nationalism in Estonia was not merely a result of the maintenance of the emergency policy of the Great Depression.

\section{NATIONALIST SENTIMENT IN GENERAL}

As in the 1920s-1930s Estonia was experiencing a period of state building, it is obvious that certain patriotic or nationalist sentiment must have existed. Success in the War of Independence, radical land reform that provided land for a large part of the population, and other such events undoubtedly increased patriotic emotions among the people. However, it is hard to notice a substantial nationalist policy in Estonia in the 1920s. ${ }^{5}$ Considering that this country was homogeneous throughout the interwar period, there was no direct reason for nationalist policy on the local level. Eighty-eight per cent of the population was Estonian. The larger minorities consisted of Russians and Germans. ${ }^{6}$ In contemporary foreign texts, Estonia was marked as a model of the treatment of national minorities. In 1925, a Law of Cultural Autonomy was adopted by the Parliament, not to mention the right of German, Russian, and Swedish minorities to address the Central Administration in their own languages. ${ }^{7}$

Nationalist ideology arose during the Great Depression. Obviously the world economic crisis that resulted in the disintegration of previous relationships and exacerbated international competition had a role in the emergence of nationalist tendencies. It is noticeable how in a situation of economic difficulties, propagation of national values becomes intensified. In March 1931, the Estonian Nationalist Club (ENC; in Estonian Eesti Rahvuslaste Klubi) was established in Tartu. The club was unique among other patriotic right-wing associations, because it had many intellectuals as its members, including economists, lawyers, and university professors. From a political point of view, this organisation supported the establishment of strong presidential rule. As far as the structure of society was concerned,

4 Kõll, A.-M., Valge, J. Economic Nationalism, 46.

5 An exception is the land reform and following frictions with the Baltic Germans, whose large landholdings were expropriated. This problem continued for several years and constituted grounds for Germany's accusations against Estonian government during the negotiations of trade agreements. Germany referred to discrimination of the Baltic Germans and used this argument to gain better conditions in trade treaties.

${ }^{6}$ Kasekamp, A. The Radical Right in Interwar Estonia. New York, St. Martin's Press, 2000, 19.

7 Royal Institute of International Affairs (RIIA). The Baltic States. A Survey of the Political and Economic Structure and the Foreign Relations of Estonia, Latvia, Lithuania. London, Oxford University Press, 1938, 37. 
they argued for corporatist structure of institutions. ${ }^{8}$ One can find the strong influence of Italian fascism in these beliefs. In many publications the members of the club referred to the Italian experience. Beginning in 1933, the club issued a monthly journal $E R K$ (acronym for the club in Estonian), which frequently included ideological articles covering the range from culture to economics.

The protagonists of nationalism put forward their ideological message in a quite outspoken manner. As an illustrative example, a quotation from the article published in 1933 by one of the ideologues of nationalism, a law professor Ernst Ein, seems to be appropriate.

The present-day Estonian nationalism is neither a bourgeois reaction nor Tsarist-dynastic patriotic state of mind, nor philological hobby. Our nationalism, similar to nationalism elsewhere, considers the nation to be the highest real socio-historical organism and its attempts are aimed at the improvement of the national power and the ultimate development of the nation's abilities. ${ }^{9}$ (My translation).

This was written in the severest year of the economic crisis. Ein considered Estonian nationalism a very important factor for the survival of the nation. According to him, the reinforcement and cultivation of national sentiment must be one of the tasks of political parties. As a result of national propaganda the solidarity between different parts of the nation increases and makes the nation more resistant to crises. In short, private and class interests must be subordinated to national interests. ${ }^{10}$ These suggestions were highly patriotic. Moreover, at that time there was no authoritarian regime yet, which would have promoted such propaganda manifestations.

Nationalist ideologues observed significant shortcomings in Estonian society, namely the implementation of nationalist ideas. On this question, they tended to rely on the state and submitted numerous propositions to the government. In some cases, they were quite successful and several laws, such as a ban on capital and property exports, were implemented. ${ }^{11}$ Nationalist-minded people welcomed larger state control and government intervention, in order to guide public life.

In 1935, Edgar Kant, another member of the ENC, wrote that the nation achieves its substance through the existence of the state. The establishment of the state is the basis for national development that must be followed by "ethnic individualisation." 12 Ethnic individualism as the result of individualisation should be understood as national self-interest opposed to other nations. However, Kant emphasises that statehood is the basis for this individualism. To a degree, this argument praises a greater role of the state.

The years after the Great Depression seemed to Kant an appropriate moment to promote "state consciousness" and the rise of national sentiments. For him the state

8 Kasekamp, A. The Radical Right, 30-31.

9 Ein, E. Mõtteid rahvuslikust poliitikast. - Eesti Rahvuslaste Klubi (ERK), 1933, 2, 27.

10 Ibid., 28.

11 Pihlamägi, M. Majandusliku mõtte ajaloost Eestis, 289.

12 Kant, E. Eestluse ülesandeid. - In: Tähiseid. Eestluse aastaraamat 1935. Ed. E. Proos. Tartu, ERK, 1935, 34. 
constituted a necessary organisational structure for the nation. An overall idea of his writing was to suggest that the nation, i.e. Estonians, should pay more attention to the decision-making process and avoid foreign influence. Ethnic individualism, intertwined with state consciousness, was his suggestion for the nation-state. ${ }^{13}$ Kant's article was published during the authoritarian period. It is, therefore, not surprising that one can find a certain justification for authoritarianism in this essay. Kant suggested that the "silent era", which followed the crisis, marked the beginning of a new rise and that society would experience a mobilisation for new growth. ${ }^{14}$

These nationalist ideas were, however, circulated in a narrow group and did not find widespread support, at least in the first half of the 1930s. Nevertheless, even the opposition in the Parliament sometimes referred to the ENC as a source of interventionist ideas already in 1932. Some other fiercest attacks on the nationalist club implied a connection between the ENC, Hitler, and radical movement in Finland. ${ }^{15}$ The accusations of a relationship with the Nazis and Finnish radicals have not found verification so far but the emergence of the matter in parliamentary debate supports the argument about the growing influence of the ENC.

There were considerably few discriminatory policies against other ethnic groups during the Great Depression. The Baltic Germans and the Jews held high positions in banking and commerce but nationalist reaction against them did not gain significant support before the last years of the crisis. However, one can suggest that such an inward-oriented nationalism is easier to emerge, because no international relationships are involved and support of ethnic majority could be easily won. In Estonia it did not emerge until the middle of the decade. The following ideological message appeared almost as a justification for some pro-nationalist decrees that were issued (e.g. in 1935 a bill limiting the role of ethnic minorities in the leaderships of private enterprises, also a decree making Estonian the language of management in enterprises).${ }^{16}$ In 1936, ERK revealed dissatisfaction with state policy towards ethnic minorities. The authors referred to the international Jewish congress that praised Estonia as the only country where the Jews had cultural self-government. The journal mentioned that the "humanistic" attitude towards the Jews had resulted in the situation where the Jews occupied the most profitable entrepreneurial fields.

This is how the Jews and the Germans live under the protection of cultural autonomy, developing successfully their own culture and their own economy... So far has gone our humanistic attitude towards minorities that the leader of the Jews, G. Aisenstadt could boast in Geneva about that. It has led to the situation where the aliens have become the masters of our trade and industry, while the Estonians remain servants. Do we have to tolerate this situation? It is time to say: No! Therefore, every Estonian must make a decision in everyday life, from whom and what goods are purchased, the state must look out that the interests of the Estonians were not ignored. ${ }^{17}$ (My translation).

13 Ibid., 30-34.

14 Ibid., 31.

15 Riigikogu täielikud protokollid (RK), 1932, 3784-3785.

16 Valitsusasutuste tegevus 1934/35. - Riigikantselei, 1935, 55, 59. See also Kõll, A.-M., Valge, J. Economic Nationalism, 55.

17 Kellel on Eestis hea elada? - ERK, 1936, 6, 135-136. 
Consequently, another "alien nation" besides the Jews that prevailed in industry and commerce was the Germans. ERK demanded that such "humanistic" policy should come to an end and the Estonians, who were political rulers in their country, should rule the national economy as well. This declaration could to a degree reflect the opinion of the authoritarian regime. Konstantin Päts, who took power in March 1934, had been a prior ENC's candidate for president ${ }^{18}$ and most likely shared its patriotic nationalism. The fact that the ENC continued its existence under Päts' authoritarian regime suggests that Päts tolerated ENC's ideology and supported this sort of patriotic propaganda. In the situation where political parties were prohibited and the public press experienced censorship, the messages of ERK could be considered as an almost official ideology.

\section{IDEAS AND POLICY OF NATIONAL ECONOMY}

This section considers the development of the ideology of economic nationalism in three periods. First, relevant ideas of the 1920s are explored to ascertain whether previous currents of thought influenced the developments of the 1930s. Then, the period of the Great Depression is dealt with. In these years the influence of the ENC on economic matters increased, as the supporters and members of the ENC released a series of ideological articles in ERK and due to the economic crisis an appeal to their propaganda grew. The last period comprises the authoritarian years, when many suggestions of the ENC (including the establishment of trade corporations, bookkeeping language, reclaiming of capital in foreign countries, etc.) were implemented by the government.

The question is whether the emergence of economic nationalism in Estonia was ideologically supported already before its actual practice or the ideas and policy were emerging in parallel. The Estonian economic historian Maie Pihlamägi suggests that the roots of nationalist economic thought were existent already in the middle of the 1920s. ${ }^{19}$ Another economic historian, Anu Mai Kõll also admits that the parallels between the mid-1920s and the authoritarian regime of the 1930s are important in assessing the roots of Estonian economic nationalism. ${ }^{20}$ Although in the 1920s the concepts reflecting nationalist economic thought did not become predominant, their existence proves economists' propensity to deviate from the liberal doctrine.

Controversies between the supporters of a controlled economy and those favouring liberal economy emerged in the discourse over the balance between agriculture and industry. In the first half of the 1920s, Estonia attempted to

18 Kasekamp, A. The Radical Right, 30.

19 See Pihlamägi, M. Eesti Vabariigi valitsuse tööstuspoliitika 1920. aastatel. - Proceedings of the Estonian Academy of Sciences. Humanities and Social Sciences, 1991, 40, 2, 108.

20 See Kõll, A.-M. Development and economic regulation. Continental influences on Estonian economic policy in the late 1930s. - Proceedings of the Estonian Academy of Sciences. Humanities and Social Sciences, 1996, 45, 3, 277-278. 
exploit the capacity of industrial production that was left behind by the Tsarist Empire. Capital was intensively invested into old industrial branches and much of production was revived, but the problem of markets became an obstacle. This led to difficulties and a reconsideration of economic policy in the middle of the 1920s. Industrial investments were curtailed and their allocation was debated. As a major change, an orientation to agricultural production occurred, which was acclaimed by the experts of the League of Nations, who visited Estonia in relation with the granting of international loan. The experts assured that the League would guarantee the loan, but on the condition that it would be used for agricultural investments. The Estonian government initially intended to acquire loan for the development of industry and communications. ${ }^{21}$

The period from 1925 to 1929 is known in Estonian economic history as a period of stabilisation and economic growth. Beginning in 1925, the government policy focused primarily on the intensification of agriculture. The aim was to develop more intensive and qualitative agricultural production, i.e. dairy farming, and thereby improve the balance of trade..$^{22}$ Nevertheless, industrial production was not entirely neglected. Some economists argued for balanced development to avoid one-sidedness.

The Minister of Finance (1924-1927), Leo Sepp became an important figure in advocating the industrial side of economy. ${ }^{23}$ Industrialists and representatives of commerce gathered around the Chamber of Trade and Industry (CTI), the first corporative employers' organisation established in 1924. The CTI had its economic monthly, The Courier of the Chamber of Trade and Industry (KaubandusTööstuskoja Teataja, hereafter referred to as KTK), which from time to time criticised government economic policy. Though Sepp was a supporter of industry, his convictions about economic policy were too radical for supposedly liberalminded industrialists and people of commerce.

Sepp, who from 1924 to 1926 was also the Minister of Trade and Industry, considered a syndicate system (i.e. corporate organisation of industrial enterprises) the best organisational form of industrial production. His views reflected the idea that the liberal concept of free competition was inappropriate for Estonia and in general outdated. If capital and markets were scarce, industrial enterprises might lose their opportunities in competition. ${ }^{24}$ Therefore, Sepp regarded syndicates as a system that allowed the arrangement of industrial development under the control of the government. Free competition as an economic struggle-creating factor was to be avoided. ${ }^{25}$ According to his preferences, government directives were better levers for the allocation of resources in industrial production than

21 Made, V. Eesti ja Rahvasteliit. Tartu, Tartu Ülikooli Kirjastus, 1999, 162-163.

22 Kõll, A.-M. Peasants on the World Market. Agricultural Experience of Independent Estonia 1919-1939. (Acta Universitatis Stockholmiensis. Studia Baltica Stockholmiensia.) Stockholm, Almqvist \& Wiksell, 1994, 70.

23 Karma, O. Eesti Vabariigi majanduspoliitika. Tallinn, Umara, 1999, 65.

24 RK, 1925, 862-864.

25 See Pihlamägi, M. Eesti Vabariigi valitsuse tööstuspoliitika 1920. aastatel, 108. 
free competition. Though Estonia had experienced a strictly regulated economy in the first years of the 1920s and state intervention was not a new idea, Sepp's beliefs constituted a courageous attack on liberal economic thought.

This ideology was to a certain extent carried out in economic policy from 1924 onwards. Industrial development became more regulated but also protected with higher customs duties. Planning and the reduction of competition were introduced and revealed in the realisation of the mentioned ideas about syndicates. It was prohibited to found new enterprises in branches where competition was becoming dangerous for existing firms. As a result, many companies merged and became monopolies. Cartels and syndicates held several industrial branches under their control, regulating the amount and marketing of production. A belief gained ground that in a situation where the main focus was on agriculture, industry had to be oriented to the domestic market. This affected credit policy and the entire environment of industrial entrepreneurship. Institutions were convinced to direct their orders to local firms. ${ }^{26}$

These actions were accompanied by propaganda to buy domestic goods, which together with high import tariffs put consumers into a tighter situation. Private entrepreneurs attacked this temporary government policy towards regulations. In 1926, the CTI declared its opinion about state monopolies, arguing that those would be harmful and not beneficial. The idea of avoiding the influence of foreign capital in certain branches of production by the creation of monopolies was declared ineffective. Since domestic capital was scarce, foreign funds were necessary and restrictions on their activities could hamper the entire economic development. ${ }^{27}$

However, this government policy remained temporary and a drawback in regulations occurred after the change of the government in 1927. An interventionist policy was discontinued; instead more conventional measures were used, such as monetary policy. ${ }^{28}$ The reversal of the previous trend meant creating better conditions for industrial expansion in foreign markets by trade agreements and lower tariffs for required raw materials. From 1929, private entrepreneurship and free competition again became the dominant ideology in government policy. ${ }^{29}$ Unfortunately, these tendencies towards the liberalisation of economy were interrupted by the Great Depression.

In its pre-crisis foreign trade policy, Estonia was lining with the prevailing doctrine of multilateral relationships, i.e. the Most Favoured Nation clause system, which was limited by the Baltic Clause. ${ }^{30}$ Tariff policy was mainly designed to

26 Pihlamägi, M. Eesti Vabariigi valitsuse tööstuspoliitika 1920. aastatel, 108-110.

27 Kaubandus-Tööstuskoja majanduspoliitilisi seisukohti. - Kaubandus-Tööstuskoja Teataja (KTK), 1926, 19, 601-602.

Pihlamägi, M. Eesti Vabariigi valitsuse tööstuspoliitika, 110-111.

The Baltic Clause reserved for the Baltic States a possibility of providing preferences for each other without extending them to other countries that had Most Favoured Nation clause agreements with the Baltic States. See, for example, Kaasik, N. The Baltic Clause in treaties of commerce. - The Baltic Countries. A Survey of the Peoples and States on the Baltic with Special Regard to their History, Geography and Economics, 1935, 2, 179-181. 
balance foreign trade and provide moderate protection for domestic industries. A more radical change occurred in 1928, when a dual tariff system was introduced. ${ }^{31}$ This alteration was designed to affect trade with those countries that had no trade agreement with Estonia. They were supposed to pay 50 per cent higher tariffs. ${ }^{32}$ The reasons for raising the tariff issue were a relatively bad harvest in the years before 1928 and an aspiration to persuade other states to reach a trade agreement with Estonia. However, the implementation of the new law was postponed to avoid a tariff war with some states but the decision to change the tariff system demonstrates government's propensity to use radical policy even in the case of temporary setback.

The world economic crisis hit Estonia particularly hard because of the country's agricultural orientation, which had been fostered in the second half of the 1920s. Estonia began to feel the severe impact of the depression in 1931. The years 1928 and 1929 had experienced a considerable economic boom, which had minimised the state role in the investment process. ${ }^{33}$ In 1930, the fall of prices had little effect on Estonia, though it was noted that the economic situation was becoming unfavourable, especially for farmers. Since the prices of industrial goods fell slower than those of agricultural products, Estonian purchase power in the world market diminished due to the large proportion of agricultural products in exports and imports of industrial goods. ${ }^{34}$ Protection of domestic agricultural producers became the first highly debated political issue during the crisis. Main controversial issues that were discussed concerned the balance between agricultural and industrial preferences, the role of the state, entrepreneurial freedom, and corporatist economy.

The economic crisis induced a range of ideas that considered capitalist economy to be outdated and suggested a search for alternatives. Pihlamägi correctly refers to the year 1932 when Leo Sepp had his speech about the crisis of capitalism. ${ }^{35}$ However, one can find similar thoughts already a couple of years earlier. Already in 1930, it was evident that the ideological trend focused on more regulated and planned economy. The economic crisis in foreign countries had a profound impact on economists. Previously exercised liberal economic policy came to be considered too eclectic and lacking properly designed aims. Undoubtedly, developments abroad, for example in Italy, towards increasing state intervention were influential.

Leo Sepp had in the middle of the 1920s suggested a more controlled economy, touching on the issues such as unnecessary competition in the market and the need for more precise planning of the economy. Though in 1930 Sepp had

31 See also Klesment, M. Eesti väliskaubanduspoliitikast kahe maailmasõja vahelisel perioodil. Eesti-Saksa kaubandussuhete baasil. - Ajalooline Ajakiri, 2000, 1 (108), 81-83.

32 Sepp, L. Eesti kaubalepingud. - KTK, 1930, 1, 11.

33 Kaubandus-tööstuskoda 1925-1935. Tallinn, Tallinna Eesti Kirjastus-Ühisus, 1935, 121.

34 The Central Bureau of Statistics in an overview of economic depression in Estonia noted that in 1929-1930 the index of prices had fallen 21 points for export goods and 7 points for import goods. - ERA, 957-4-136, p. 4.

35 Pihlamägi, M. Majandusliku mõtte ajaloost Eestis, 287. 
become the chairman of the CTI, which was a supporter of liberal doctrine rather than state intervention, he still suggested tariff protection, the elimination of competition, and an elaborate plan for development. Free competition in the market became a target of interventionist critique. For Sepp, free competition created a system of parallel enterprises which rivalled each other because of similar interests. According to the logic of Sepp and his supporters, the state economy did not gain from competition. Competition meant a complicated credit policy, which led to a situation where none of the enterprises were viable. According to Sepp, there was a need for a more planned and far-reaching economic policy that would set direction for many years. "Our anarchistic and short-sighted economic policy" was the judgment to the contemporary Estonian economic policy by the author who summarised Sepp's critique in $19300^{36}$

An argument that was repetitively used declared that Estonia had to follow the practice of other states. Since the rest of the world was moving towards state intervention and restrictions of economic freedom, small states had to follow their line. This was also the issue Sepp touched upon in 1930: "Should we follow the patterns that powerful states have taken and attempt to create a certain independent economic unit or remain faithful to the principle of free trade?" His answer, that there was no other way than to strive towards economic independence because improvement in international trade relations in the nearest future was improbable, ${ }^{37}$ suggests that Sepp did not believe in the re-liberalisation of the international economy.

Consequently, already in 1930 there gradually emerged an ideology that resembled some ideas of nationalist economic thought. It is, however, difficult to observe its weight in public debate. Sepp, as the main protagonist of this ideology, held several quite important posts and his opinion was of great weight, considering that at the end of the crisis he served as the adviser to the Prime Minister in economic affairs. On the other hand, in 1930 a rapid change towards regulated and self-supportive economy was impossible. Previous years had shown considerable growth in relatively liberal conditions. Support for government intervention could come mainly from those groups that first began to experience the pressure of declining demand, i.e. agricultural producers (a bill restricting grain import was introduced already in July 1930).

One is inclined to assume that Sepp retained his negative opinions about free competition expressed in the 1920s. In 1930, due to the world economic crisis, a criticism of free trade and a suggestion to work towards a self-supportive economic unit appeared in his views. Among his other ideas of 1930 were also tariff protection and government intervention in order to support certain branches of production. ${ }^{38}$ Although these ideas were not posed within the context of exaggerated patriotic sentiment, there was a clear indication of controversy between the national economy and private entrepreneurship.

36 Taklaja, J. Kavakindlamast majanduspoliitikast. - KTK, 1930, 16, 378-379.

37 Ibid., 378.

38 Ibid. 
The economic crisis caused a debate over the necessity for tariff protection. One of the theses put forward was that free trade had lost its importance and did not correspond to modern standards. Advocates of a greater state role argued that the state had extended its responsibility, i.e. it had to take care of the welfare of its citizens, not only provide the conditions for profit maximisation. Therefore, some advocates of state intervention related tariff barriers with social policy. A simplistic argument published in an article in 1930 declared that state social policy, that is social protection of its citizens, justifies tariff protectionism. ${ }^{39}$ Tariffs, according to this publication, were not always designed to increase economic gain but to serve social aims that require a sacrifice in private income. Accordingly, a modern state must interfere if some social groups are in a difficult situation and tariffs must become a tool of social regulation. Some leading figures of state enterprises and economists expressed analogous beliefs, arguing that private initiative was unable to overcome the difficulties caused by the spontaneous pursuit for profit. Or, that capitalist development had rationalised the process of production so far that it was irrational for society and had to be regulated. ${ }^{40}$ Thus, in a deepening crisis the ideas attacking the liberal capitalist system became increasingly articulated.

In December 1932, when Estonia was already experiencing the severe impact of the crisis, Sepp gave a speech that argued for the transition from liberal economy to state regulation. The speech was published in an article entitled "Kapitalismi kriis" ("The crisis of capitalism"). For Sepp, capitalism was an individualistic economic system, which was characterised by its organisation of production. However, he considered capitalism a historical era, implying that similar to other historical periods, capitalism was coming to be exhausted. Sepp argued that in many countries economic policies were implemented, which reflected less and less a liberal capitalist approach. One aspect he mentioned was technical progress that had changed the process of production and made it uncontrollable. The supply of products was exceeding the maximum of demand. To keep production limited, more regulations are required but this undermines economic freedom, which is one precondition of capitalism, and as a consequence there is no liberal capitalism. ${ }^{41}$ In general, his argument was that the capitalist system was unable to self-regulate and an alternative approach was required.

Sepp stated that the Great Depression was not simply another crisis but marked the bankruptcy of the entire capitalist system. Because of the technical and intellectual development the old system cannot function without destabilisations. $\mathrm{He}$ was convinced that a new system had to be developed, which would embrace more collective control and planning but would not ignore private initiative either. It seems that Sepp's views were strongly influenced by a British financial expert Sir Arthur Salter, who suggested a corporatist economic system. ${ }^{42}$

\footnotetext{
39 Taklaja, J. Tollikaitse ja sotsiaalpoliitika. - KTK, 1930, 6, 121-123.

Sepp, L. Kapitalismi kriis. - ERK, 1933, 1, $23-25$.

Sepp, L. Kapitalismi kriis, III. - ERK, 1933, 3, 82-84.
} 
The Great Depression was a strong argument for interventionists. References to fascist Italy or planned economy of the Soviet Union became more frequent, though these cases were treated carefully and not always brought as positive examples. However, the situation in the world market, which showed disintegration of international trade, rising tariff barriers, and reorganisation of the trade system, suggested that a regulative economy was necessary. As a result, the experience of the Great Depression designed the ideology and policies of the 1930s. Leo Sepp, who was not directly involved in political debate, had a considerable influence on the development of economic policy, especially visible through the 1930s. In the late 1930s, he became the Minister of Economic Affairs and to a large extent retained his views about the disadvantages of liberal economic policy.

The end of the economic crisis marked also an end of a political era in Estonia. In March 1934, Konstantin Päts, who held the post of Prime Minister, organised a coup in order to prevent the fall of power into the hands of the Veterans' League. ${ }^{43}$ Päts declared that the Estonian nation was "sick" (referring to political instability and the emergence of radical right) and that the situation required intervention. ${ }^{44}$ The years that followed came to be known as "the silent era" (vaikiv ajastu) because of the severe restrictions implemented in political and economic life. The Parliament was first temporarily and then permanently dissolved. Political activities of the opposition were restricted and organisation of parties was forbidden. A state of emergency was declared in the country. In his speech of the New Year's Eve (1934/35), Päts claimed that the coup of 12 March was necessary to save the country and that a radical political take-over was not made in favour of any particular group. $^{45}$

The establishment of the authoritarian regime had a direct influence on the enforcement of nationalist ideology. Ideas about state intervention in the economy and the corporatist system, which were previously advocated by the ENC and Leo Sepp, became predominant. Päts even mentioned Mussolini and the Italian experience as a positive example. ${ }^{46}$ Therefore, one may assume that the ideological current of nationalist economic doctrine, which during the crisis had still been secondary, became the official doctrine for authoritarian policies. The infiltration of nationalist ideas into government policy and their implementation were somewhat compensated by a stabile political situation that authoritarianism brought about. Therefore, but also because of the oppression of opposing ideas,

43 The Veterans' League was an organisation of those who had fought in the War of Independence in 1919-1920. Its ideology was strongly nationalist, reflecting the general idea of "the integral nation". Its aim was the creation of a national state, acting directly in favour of the nation and uniting Estonians into one organic unit. See Kasekamp, A. The Radical Right, 65-66.

44 Critical treatment of Päts' regime, though in form of memoirs, can be found in Tomingas, W. Vaikiv ajastu Eestis. New York, Eesti Ajaloo Instituut, 1961.

45 Valge, J., Pajur, A. (eds.). Poliitilise mõtte ajaloost Eestis 1930-1940: dokumente ja materjale. Tallinn, Jaan Tõnissoni Instituut, 1995, 100.

46 Ibid., 102-103. 
the emergence of deliberate nationalist economic policy did not raise explicit disagreement within liberal groups.

In 1934, Leo Sepp asked in the ERK: "Has the new Estonian way become clear?" His answer was that the state was still exercising transitional and temporary policy. He described how in many states there was a tendency to move away from liberal egoism and plan new aims considering the welfare of the nation and society. Sepp, being consistent in his opinion, reinforced his negative attitude towards liberal economic policy. He mentioned that the modern trend of economic policy was resembling more the idea of Gemeinnutz geht vor Eigennutz (common need before individual need), which was referring to Nazi Germany. However, he discouraged borrowing strategies from foreign countries and asserted that Estonia had to find her own way. ${ }^{47}$

By the second half of 1934 , the economic situation had already improved, ${ }^{48}$ which probably helped the regime to gain support. ${ }^{49}$ The temporary measures of the crisis were largely maintained and new regulations introduced. One of the major changes was the introduction of a corporative structure of institutions. Corporatism in Estonia was considered rather mild compared to Italy or Austria. A member of the ENC, Juhan Vilms, who published an article on corporatism in 1935, stated that a specific feature of Estonian corporatism was its "democratic evolution". He argued that this development had not occurred due to totalitarianism from the top down, but on the contrary, evolved for years from below. The emphasis had been on the basis of society, its division into corporations, as opposed to focusing on subordination and totality. The author concluded that at that moment, Estonia was experiencing "democratic corporatism". ${ }^{50}$ This statement is rather awkward, considering that the corporative system that appeared was mainly the product of the authoritarian regime. However, the ENC had considerable influence on the formation of the regime's ideology. Demands to diminish the role of ethnic minorities in economic life and make Estonian the language of business administration, to "nationalise" ${ }^{51}$ private capital, implement state control over capital and large enterprises, and to control the labour market were presented to Päts and to the Minister of Economic Affairs, Karl Selter, in November 1934. ${ }^{52}$ The ENC's support for the corporatist structure was evident as well.

47 Sepp, L. Majanduspoliitilised tuultepöörised. - ERK, 1934, 5, 76-78.

48

49 Cow already in mid-1933, after the devaluation of national currency, which improved Estonian export trade and created favourable conditions for domestic industry.

In December 1934, the CTI gave a positive assessment to Estonian economy and, implying that economic groups were not participating in legislative work, indirectly suggested the enforcement of corporatist tendencies that would involve institutions in the decision-making process. See: Positiivne hinnang Eesti majandusele. - KTK, 1934, 24, 421-425.

50 Vilms, J. Korporatiivsete ideede rakendamisest välismail ja Eestis. - ERK, 1935, 4/5, 89-94.

51 This refers to the idea of prohibiting investments and capital export to foreign countries in order to secure domestic capital entirely for local economy.

52 ERK-ide majanduspoliitilisi nõudeid. - ERK, 1934, 9/10, 168-170. 
Economic life underwent a change towards the increasingly regulated system. It may be argued that from 1935 economic nationalism was already a deliberate practice. The industrial programme of 1935 , which was supposed to introduce a profound alteration in the relationship between private and state economy, became the landmark of this trend of converting temporary measures into long-term policy. The essence of this change was considered in the new relationship between private and state economy, meaning that the state takes most of the initiative and private enterprises only fulfil the state programme. This was regarded as a new quality in Estonia and supported by an argument concerning the unavoidability of the development towards a more regulated system, primarily because of the increased responsibility of the government. ${ }^{53}$

In a situation where economic policy required increased ideological support, reliance on theorists of economic nationalism gained ground. Since there was no continuation of the economic crisis, justification to proceed with interventionist policy had to come from other sources. At that moment, Friedrich List's theory about pro-nation economics became noticeable. Ideologues, arguing for nationalist economic policy, began to describe how classical economic thought had given way to the nationalist economic doctrine. Classical economic theory was considered cosmopolitan and too universal. To replace the system of private interest, the nationalist economic system was promoted, emphasising that thereby unique needs of a nation are taken into account in order to improve the welfare of the entire nation. In general, the protagonists of nationalist theory considered the move from liberal capitalism to a nationalist economic system as an evolutionary development. ${ }^{54}$

"Regulatory economic policy" became the slogan of pro-interventionists. Some argued that Estonia had never experienced a real free market economy because there had always been some restrictions by the state. The idea put forward by the most ardent interventionists was that at that moment the country needed more extensive regulations than ever before, because economic policy could be quickly implemented and the results would follow soon ${ }^{55}$ The ideological beliefs of the authoritarian regime were quite parallel to these ideas. Regulatory economic policy was declared as a necessity. Among other propagandistic arguments that served to justify interventionist policy, references to social egalitarianism and common welfare were made. Of considerable influence was the argument that the Estonian economic unit could not be the playground of liberal experiments, but had to be guided by a carefully planned and organised economic policy. ${ }^{56}$

The regime's official standpoints may be summarised using Leo Sepp's speech in 1938 about choosing between free market and regulated economy. Sepp repeated

53 Juhitud majandus valitsuse uues tööstuskavas. - Vaba Maa, 1935, 9. okt.

54 Poom, E. Rahvus ja majandus. - In: Tähiseid. Eestluse Aastaraamat 1935. Ed. E. Roos. Tartu, ERK, 1935, 35-41.

55 Ajude trust Eesti majanduselu juhtima. - Vaba Maa, 1935, 29. okt.

56 Reguleeritavast majandusest. - Uus Eesti, 1938, 13. dets. 
his old beliefs that regulatory policy had to be practiced because the capitalist system had become uncontrollable, production had increased enormously due to technical revolutions, supply surpassed the consuming power, etc. As almost a mandatory part of his justification for interventionism, a reference to other states was provided.

Miracles have occurred. Irrefutable economic beliefs have collapsed. Because of the regulation and direction of economic life in the desired course. If there had not been regulation of economic policy, beginning with Roosevelt, the policy of the Sterling bloc and ending with Hitler, the overcoming of the economic crisis would have been questionable. ${ }^{57}$ (My translation).

Sepp also justified the practice of interventionist policy in Estonia, presenting it as a necessary part of contemporary economic policy. He attacked the arguments that implied increasing corruption, which was characteristic of planned economy. Furthermore, Sepp stated that the private economy had to meet new requirements and there was no place for unlimited egoism in the new system. In general, he viewed the regulatory policy as a means of driving the Estonian economy out of backwardness.

The general management of Estonian economy from one central point in favour of common welfare is not a disputable or deniable question any more. It is an inevitable necessity from the point of national economy... in Estonian poor and backward national economy. Take a look at our neighbours. All of them, Denmark, Sweden, Finland, and let us be honest, even Latvia are ahead of us regarding their wealth... and standard of living. Therefore, our first and most important goal is to increase our national income, take care of just [resource] sharing process to guarantee the wealth of our nation... ${ }^{58}$ (My translation).

\section{CRITICS OF NEW MEASURES}

The previous section followed the development of one ideological side, largely ignoring that actual economic policy, at least during the economic crisis, differed from that. Moreover, opposite ideas existed on the other side of the ideological spectrum. However, one should not attempt to draw a clear dividing line between the two sides, as there were elements that both of them shared. Therefore, it is reasonable to speak about those who were more inclined to liberal economic thought and those tending to support nationalist ideas in economics. In the situation where polarisation of economic thought became growingly intensive, those arguing for retention of the free market system gathered around the CTI. In the present context, they can be called liberalists. The ideas and expressions of liberalists are included in order to explore the criticism of nationalist economic thought.

Industrialists reacted to growing tendencies of regulative economy already at the beginning of the crisis. To a degree, liberalists admitted that the situation of crisis necessitated certain emergency measures that could not be avoided. Joakim

57 Sepp's speech in 1938, cited in Valge, J., Pajur, A. Poliitilise mõtte ajaloost, 162-164.

58 Ibid., 169. 
Puhk, one of the key persons on the side of liberalists and a prominent leader of the CTI, acknowledged in 1930 that international "economic solidarity" (market freedom in Puhk's phraseology), which he considered the primary precondition of development, had begun to decline. This required more regulatory policies in the Estonian economy. However, Puhk was disappointed in a growing tendency towards unconventional measures. The first was the grain monopoly introduced in July 1930. According to him, traditional methods such as tariffs should have been used. ${ }^{59} \mathrm{~A}$ general remark that was repetitively made by Puhk and other liberalists concerned the balance between agriculture and industry. Although they conceded that agriculture had historically an important role in Estonian economic life, their criticism was directed against government policy, which since the middle of the 1920 s had overemphasised the support for agricultural producers.

The liberalists' critique saw behind growing state intervention the influence of socialism. Socialism, as they concluded, had cultivated in Estonia a belief that the only possible way to develop the national economy is the one directed by state. ${ }^{60}$ In February 1931, the monthly of the CTI pointed to several mistakes in economic policy. Most of the criticism was directed against state aspirations to take over the role of entrepreneur from the private sector. The state had arguably begun to act as a competitor to the private sector which led the CTI to question the economic order of Estonia, whether it was capitalist or socialist. The CTI addressed several notes to the government, pointing to the harmful nature of this policy, but without any results. ${ }^{61}$ In July 1932, Puhk formulated this problem as a crucial dilemma between individualism and communism. ${ }^{62}$

In the Parliament the liberal opposition argued for a free market economy and restricted state intervention. ${ }^{63}$ In 1933, their leader Jaan Tõnisson declared that the Estonian economic policy during the crisis had taken a detrimental turn. Restrictions on the private economy imposed by the state were considered unacceptable by this liberal group. One of their aims was to reform the existing financial policy. ${ }^{64}$ Though the influence of this group was not large, they managed to form a cabinet in 1933 and devaluated the national currency ${ }^{65}$ which became the turning point of the crisis in Estonia.

It must be noted that though the CTI held a liberal economic position, it included in its views certain elements that resembled a nationalist economic policy. The demand for the protection of domestic industry was one example of this. Of course, this is not surprising, considering that industrialists had great influence over that organisation. The arguments of the CTI stated that industrial protection would

59 Puhk, J. Meie majanduspoliitika arvustustules. - KTK, 1930, 21, 497-500.

60 Pihlamägi, M. Majandusliku mõtte ajaloost Eestis, 293-294.

61 Ülevaade meie majanduslikust seisukorrast. - KTK, 1931, 3, 37-38.

62 Abinõusid majanduskriisi lahendamiseks. - KTK, 1932, 13, 217.

63 See Kõll, A.-M., Valge, J. Economic Nationalism, 48.

64 RK, 1933, 765-767.

65 See Valge, J. Okkaline devalveerimine: Eesti krooni kursi ümberhindamine aastail 1931-1933. - Akadeemia, 1997, 8, 1605-1643. 
reduce unemployment. Therefore, according to Puhk, "our primary concern should be the protection of domestic industry and securing the internal market for industry as much as possible". ${ }^{66}$

Puhk's article about industrial protection revealed quite mercantilist views. The following passage by Puhk could well belong to some protagonist of nationalist economic policy.

Let us remember that every cent we spend on foreign goods is almost a crime against our country and nation if the same goods can be produced in our country. Every such cent would be like stolen from our workers, from our national economy, because it cuts down the purchasing power, discourages state finances, and reduces the capacity of the domestic market. ${ }^{67}$ (My translation).

This suggests that although liberalists recommended a minimum role of the state in domestic economic policy and a restricted influence of the government on private entrepreneurship, they argued for protectionist foreign economic policy. Apparently, this was a response to the government policy that favoured mostly agriculture. On the other hand, the deepening world economic crisis was a reason to require industrial protection, considering that similar practice was becoming popular in many countries. The CTI admitted that state intervention in economic life had so far had only negative effects. To strengthen the argument, a reference to European and American experience was made, implying that intervention had only deepened the crisis. Paradoxically, at the same time there was a suggestion that entrepreneurship should be organised into trusts and cartels to be able to plan production and marketing. ${ }^{68}$

Imre Lipping suggests that the beginning of the authoritarian regime was to a certain extent welcomed by industrialists because the political struggle between the left and the right, which had created uneasy conditions for entrepreneurs, ended. ${ }^{69}$ This argument should be taken with reservation. Industrialists continued their criticism against state interference in the private sphere and demanded cancellation of the emergency measures that were introduced during the crisis. Their slogan was: "Less state economy and more private entrepreneurship!" Liberalists could not accept such "state socialist tendencies", which, according to them, gained ground in economic life. They argued that private initiative had always been more successful than a bureaucratic state economy. After all, it was the private sector that supported the public sector with taxes and, therefore, the undermining of private interests would be harmful to the entire country. ${ }^{70}$ The CTI's chairman Puhk kept emphasising that state intervention in the economy was one

66 Puhk, J. Kaitset kodumaa tööstusele. - KTK, 1931, 17, 280-281.

67 Ibid., 281.

68 Majanduspoliitilisi probleeme. - KTK, 1931, 23, 387.

69 Lipping, I. The Emergence of Estonian Authoritarianism. - In: Baltic History. Eds. A. Ziedonis Jr., W. L. Winter, M. Valgemäe. Columbus, Association for the Advancement of Baltic Studies, 1974, 214.

70 Eesti maailmavaateline areng ja Eesti majanduselu. - KTK, 1935, 18, 329-331. 
of the main problems of Estonia. He even went as far as declaring state interference to be an element of dictatorship. ${ }^{71}$ His reference to the lack of democracy in Estonian political life was clear and bore rather negative connotation. Considering this criticism, Lipping's conclusion that the emergence of the authoritarian regime was accepted by the Estonian public because of the economic growth that followed ${ }^{72}$ becomes disputable.

In the second half of the 1930s, the monthly journal of the CTI kept issuing articles about the negative effects of the extended role of the state in economic life. Nevertheless, its criticism was not as articulate as it was two-three years before. Some authors developed ideas about the harmful effect of oppressed private initiative and accused the state of developing a parallel system of enterprises which private entrepreneurs could not compete with. ${ }^{73}$ Though liberalists relied on the basic beliefs of the classical economic doctrine, their aspirations were to a certain extent overshadowed by their own narrow interests. Therefore, state regulations that promoted protection of domestic industry or favouring local tradesmen were not criticised. Moreover, the corporate system included trade corporations in legislation and this also appeased liberalists' reaction against intervention in the private sector. ${ }^{74}$

\section{CONCLUSIONS}

To summarise the main points reflecting the existence of the elements of nationalist economic thought in Estonia, one should pay attention to the relevant ideas that evolved already in the 1920s, probably due to the economic difficulties in the first half of the decade. These ideas began to gain importance at the beginning of the world economic crisis. Leo Sepp, a well-known advocate of anti-liberal economics, came to be supported by explicitly nationalist ideology of the ENC. While Sepp did not emphasise nationalist thought but rather the alternative economic policy of intervention, the ENC was overtly arguing for an inward-oriented economic nationalism. Sepp's ideas about reorganising the economic system were similar to the policies exercised by nationalist economics but his approach was one of an economist and without over-exaggerated nationalist sentiment. The ENC supported his suggestions about a greater role of the state, as it fit in with the aim of increasing national wealth. After the crisis, both ideological lines, Sepp's and the ENC's, began to run parallel and complemented each other, as they appeared in the policy of the authoritarian regime. The ENC provided nationalist ideology and Leo Sepp the economic doctrine, which assisted the government in maintaining interventionist policy.

71 Karma, O. Eesti Vabariigi majanduspoliitika, 134.

72 Lipping, J. The Emergence, 214.

73 Kas eraalgatuse kriis või interventsionistlik majanduspoliitika. - KTK, 1936, 24, 582-583.

74 Kõll, A.-M., Valge, J. Economic Nationalism, 63-64. 


\title{
MAJANDUSLIKU NATSIONALISMI LÄHTEKOHAD SÕDADEVAHELISES EESTI VABARIIGIS
}

\author{
Martin KLESMENT
}

Vaatluse alla on võetud mõned eesti majandusliku natsionalismi ideoloogiat ja praktikat mõjutanud inimesed ja nende ideed sõdadevahelises Eesti Vabariigis. On lähtutud seisukohast, et 1930. aastate teisel poolel tugevnenud majandusliku rahvusluse praktika ei tulenenud ainult suure majanduskriisi aegsest ad hoc majanduspoliitikast, vaid oli Eesti majanduspoliitika kujundajate intellektuaalses arsenalis olemas juba 1920. aastatel.

Esimeses osas on tausta loomise eesmärgil vaadeldud lühidalt eesti rahvuslikku ideoloogiat antud perioodil. On järeldatud, et rahvusluse rõhutamine leidis aset alates suure majanduskriisi jõudmisest Eestisse. Üheks rahvusluse tõusu indikaatoriks oli Eesti Rahvuslaste Klubi loomine 1931. aastal ja selle organisatsiooni sõnavõtud nii üldistel kui majanduslikel teemadel. Autori hinnangul säilitas klubi ideoloogide poolt propageeritava tähtsa koha ka vaikiva ajastu perioodil.

Teises osas on jälgitud majandusliku rahvusluse ideede ja nendega seostatavate vahendite kasutamise levikut nii majanduskriisi ajal 1920. aastatel kui ka 1930. aastate teise poole autoritaarse perioodi jooksul. Võtmeisikuna kerkis esile majandustegelane ja minister Leo Sepp, kelle avaldusi on ka lähemalt käsitletud. Leo Sepp avaldas majandusliku rahvusluse poliitikale tugevat poolehoidu juba enne majanduskriisi jõudmist Eestisse. Kriisiaastad olid tunnistajaks Leo Sepa vastavate vaadete konsolideerumisele. Muu hulgas viitas ta kapitalistliku süsteemi aegumisele ja vabaturumajandusliku süsteemi üldisele kokkukukkumisele. Leo Sepa ja rahvuslaste klubi ideed said autoritaarse režiimi ajal domineerivaks ja majanduslik rahvuslus alates 1935. aastast keskseks majanduspoliitiliseks suunaks.

Kolmandas osas on võetud vaatluse alla kriitika majandusliku rahvusluse ideoloogia ja praktika kohta, mida esindasid töösturid ja kaubandustegelased. Kuigi kahe pooluse vaated osaliselt kattusid, kritiseerisid majandusliku rahvusluse vastased riigi suurenevat rolli majanduselus. Teisalt pooldasid töösturid omamaise tööstuse kaitsmist ja siseturu reserveerimist kohalikele tootjatele. Selles osas võib majandusliku rahvusluse pooldajate ja nende kriitikute vaateid kattuvaiks lugeda. Kokkuvõttes on järeldatud, et majandusliku natsionalismi elemendid, mida juba 1920. aastatel esindas Leo Sepp, tugevnesid suure kriisi ajal ja kujunesid hiljem autoritaarse režiimi majanduspoliitilise doktriini osaks. Sellele aitas kaasa üldine rahvusluse tõus ja riikliku sekkumise suhteline edu kriisijärgsetel aastatel. 